\title{
Privatisation And Entrepreneurship Development In Nigerian Economic Growth
}

\author{
Olusola Igbari, Ph.D. \\ Crowther Graduate Theological Seminary, \\ Abeokuta Ogun State, Nigeria \\ (In Affliation With Ajayi Crowther University, Oyo)
}

\begin{abstract}
The fundamental goal for the pursuit of efficient growth; equity; support of entrepreneurship development; alleviation of poverty and environmental protection as well as meeting other needs is seemingly the desire of the Nigerian government and one of its arsenal of actualizing this goal is fund generation through privatization of the public sector. But the reality of the phenomenon has become a conceptual trump card, so politicized that it no longer implies the same meaning it did from the beginning. The study used descriptive method to examine Privatization as a phenomenon and its attendant effects on Entrepreneurship Development vis-à-vis the Nigerian Economic Growth through secondary data collection. It observed the need for the participation of both government and private sector in the development of entrepreneurship which is a key factor to the growth of the nation's economy. It concludes that the failure of the government in its privatization policies and serious support for small scale industries has contributed to the underdevelopment of the economy. It recommends that government should at all levels establish a strong support and create an enabling environment for small scale industries to thrive.
\end{abstract}

Key Words: Privatisation, Entrepreneurship, Development, Economic Growth.

\section{INTRODUCTION}

Today, people often talk about privatization and it is often said that what the nation needs is more of privatization because the evidence of its accelerated interest in the last two to three years is striking. But the reality of the phenomenon has become so politicized that it no longer implies the same meaning it had from the beginning. It has become one of the most familiar words that are used without its life changing ideology. Shirley stated that today, Governments of very different political and ideological streams are bent on privatizing, and governments that are already privatizing are moving from selling small retail outlets and industries to selling larger mining and infrastructure enterprises. ${ }^{1}$ Fund generation through privatization of the public sector is the fundamental goal for the pursuit of efficient growth; equity; support of entrepreneurship development; alleviation of poverty and environmental protection as well as meeting other needs is arsenal in the hand of the government. This implies that every government or leadership desire to see that the economy of the nation grows and entrepreneurship development is totally met, but these goals do not seem being met.

Gberevbie et al said that Privatization is an act of government withdrawal of control from the working of an aspect of the economy and leaving same in the hands of the private sector operators for more efficient use of the resources and to bring about development in the

1M.M. Shirley, The What, Why, and How of Privatization: A World Bank Perspective, 60, (Fordham: Pritchard Press 1 992), 23. 
society. ${ }^{2}$ What happens after government withdrawal of control seems not to be the concern of any body, the reality is far from what is been said. According to Shirley, the World Bank's interest in privatization stems from its fundamental goals to help its borrowers achieve efficient growth with equity, while reducing poverty and protecting the environment. ${ }^{3}$ Hence, privatization can be an important means to these ends. She noted further that three questions about privatization should be addressed.

The first question is twofold: what is privatization and what is happening in privatization? The second important question with respect to privatization is: why should you privatize? Finally, the question of how to privatize must be addressed. ${ }^{4}$

These questions are important and apparent to ensure that proper attention is given to a detailed study of the whole concept with keen interest to know the needful about privatization, entrepreneurship development and economic growth of the nation. They are designed to exray the relationship with each other and to avoid the situation of using privatization as a conceptual trump card to entrepreneurship development and economic growth.

\section{DEFINITION OF CONCEPTS: PRIVATIZATION, ENTREPRENEURSHIP DEVELOPMENT AND ECONOMIC GROWTH}

Explaining the crucial concepts leading to the purpose of this paper is very appropriate due to the fact that these terms have been used with different touches in many ways to mean different things from time to time; hence, it is needful explaining them in the context of this paper.

\section{Privatization}

According to Dudley, the Economist magazine introduced the term 'privatization' (alternatively 'privatisation' or 'reprivatization' after the German Reprivatisierung) during the 1930s when it covered Nazi Germany's economic policy. ${ }^{5}$ Kammerer noted that it is not clear if the magazine incidentally invented the word in English or the term is a loanword from the same expression in German, where it has been in use since the $19^{\text {th }}$ Century. ${ }^{6}$

Privatization as defined by Onah is a means of relying more on the private institutions of the society and less on government to satisfy people's needs or it applies to a deliberate policy to reduce the role of government and subsequently expand the role of the private sector. ${ }^{7}$ While Abdullahi sees privatization as the divestment from state-owned enterprises and transfer of ownership to private holding by government as a consequence of their poor economic performance and provision of inefficient services. ${ }^{8}$ Savas adds that it is the changing from an arrangement with high government involvement in enterprises to one with less government involvement. ${ }^{9}$ In other words, privatization is a subsequent instrument used to reduce the role

${ }^{2}$ D.E. Gberevbie et al. "Deregulation Policy and Development in Nigeria: The Petroleum Sector Experience, 1999 2014," in Journal of Social Development in Africa, Vol. 30, No. 2, 2015, 131.

3M.M. Shirley, The What, Why, and How of Privatization: A World Bank Perspective, 60, 23.

4M.M. Shirley, The What, Why, and How of Privatization: A World Bank Perspective, 60, 23.

${ }^{5}$ E.R. Dudley, The Pursuit of Reason: The Economist, 1843 - 1993, (Harvard: Harvard Business School Press, 1995), 946.

${ }^{6}$ J.A. Kammerer, Privatisierung: Typologie - Determinanten - Rechtspraxis - Folgen, (Germany: Mohr Siebeck Verlag, 2001), 7.

7F.E. Onah, “The Impact of Economic Globalization on Nigeria's Industrial Sector," Nigerian Journal of Social Sciences, 4(1), 2004, 254.

8I.B. Abdullahi, "Privatization of Nigerian Public Enterprises: Lessons from Developed Countries," Ilorin Journal of Business and Social Sciences, 9, No. 1 \& 2, 2004, 105.

${ }_{9}$ E.S. Savas, Privatization and Public-Private Partnerships, (Chatham, NJ: Chatham House, 2000), 187. 
of government and expand the role of the private sector or transfer of its investment to the private sector as a result of perceived inefficiencies. Gberevbie, agreed with Abdullahi who further explains that privatization of private enterprise is based on the premise that private sector is an instrument for realizing productive, allocative, efficiency and higher economic growth in a society. ${ }^{10}$

Beeman states that the word privatization may mean different things depending on the context in which it is used. It can mean moving something from the public sphere into the private sphere, but it may also be used to describe something that was always private, but heavily regulated, which becomes less regulated through a process of deregulation. The term may also be used descriptively for something that has always been private, but could be public in other jurisdictions. ${ }^{11}$ Metzger averred that:

Private entities provide a vast array of social services for the government; administer core aspects of government programs; and perform tasks that appear quintessentially governmental, such as promulgating standards or regulating third-party activities. He mentions an expansion of privatization that includes health and welfare programs, public education, and prisons. ${ }^{12}$

In this way, the process and premise which refers to the divestment of the government of its ordinary shareholding from a state-owned enterprise promises better provision of goods and services at lower cost in a society for the development of the people and growth of the economy.

Devroye, Slyke, Nwokoma state that true privatization is not theoretical or speculative, but measurable, attainable and realistic, and directed towards small scale development and economic growth. ${ }^{13}$ Consequently, privatization must be geared towards answering the growth and developmental questions which the small scale industries are asking in the light of the huge resources in the hands of the government and that are concentrated in the hands of few people while the majorities are being confronted with the exigencies of life and wrestling with the ultimate meaning of such life. ${ }^{14}$ Any approach different from this would amount to developmental irrelevance and production of rootless economic growth. This means that the aim of privatization implies participation and exploration by the government in emphasizing the activity that produces privatization.

\section{Entrepreneurship Development}

Metu and Nwokoye describe 'Entrepreneurship' as a word which stemmed from the French word 'entreprendre' meaning to understand. ${ }^{15}$ Hence, entrepreneurship is the process of understanding activities concerned with identifying and exploiting business opportunities while assuming its attendant risks. Gillian perceived entrepreneur as a person who starts and organize a commercial enterprise especially one having financial risk. He sees an entrepreneur as an individual who has the ability to visualize and evaluate business opportunities, gather the

\footnotetext{
${ }^{10}$ D.E. Gberevbie et al. "Deregulation Policy and Development in Nigeria: The Petroleum Sector Experience, 1999 2014," in Journal of Social Development in Africa, Vol. 30, No. 2, 131.

11. Beeman, "Privatization and Political Accountability," Fordham Urban Law Journal, 28(5), $2001,1507$.

${ }^{12}$ G. Metzger, Privatization as Delegation, (London: Colum L. Rev, 2003), 1367.

${ }^{13}$ D. Devroye, "Who wants to Privatize Social Security? Understanding why the Poor are wary of Private Accounts," Public Administration Review, 63(3), 2003, 316 - 317.

${ }^{14}$ A.I. Abiodun, "Privatization of Public Corporations in Nigeria: The Fate of the Masses," International Journal of Economic and Development Issues, $5(1 \& 2), 2005,103$.

${ }^{15}$ A.G. Metu and E.S. Nwokoye, "Entrepreneurship Development in Nigeria: Prospects and Challenges," https:// www.researchgate.net/publication/277021008, Accessed 23/04/2019.
} 
necessary resources to take advantage of them and initiate appropriate actions to ensure success and he is a risk taker. ${ }^{16}$

Marthy notes that entrepreneurship is the bedrock for the human activities and a major stimulator of enterprise without which any economic development cannot thrive. Hence, he averred that such stimulator is capable of transforming man from a nomad to a cattle rearer, to a settled agriculturist, to a trader, to an industrialist and finally to multinational conglomerate. ${ }^{17}$

Ewurum and Ekpunobi, in concordance with Okonkwo and Okonjo-Iweala, opine that the essential drivers of economic growth and prosperity in a modern economy is a strong entrepreneurial background, having the capacity to empower the populace, providing greater possibilities for the use of available local raw materials with the strength of encouraging vertical and horizontal connectivity. ${ }^{18}$

Consequently, Metu and Nwokoye agreed with Chibundu stating that the findings of research and empirical proof have shown that many countries which encouraged entrepreneurship also have significant evidence of poverty reduction. ${ }^{19}$ To them, domestic entrepreneurs stimulate private consumption, ownership and entrepreneurial abilities, generate employment, help diversify economic activities and make significant contributions to export and domestic trade while utilizing local raw materials.

On the other hand, development as a concept has generated different meanings amongst scholars. Oni \& Bello, perceived development as a practical persistent process of positive change in the quality of life of an individual or group of people by the reason of opportunity to better living condition. ${ }^{20}$ For Todaro, it is a multifaceted process which involves the reorganisation, reorientation and revitalization of the entire economic and social system and the improvement of income and output that combines radical changes in institutional, social and administrative structures as well as in popular attitudes, customs and beliefs. ${ }^{21}$

Adamolekun looks at development in terms of improving the living conditions of people amongst the world's poorest nations. He posits that development entails a higher quality of life, higher income, better education, higher standards of health and nutrition, less poverty in society, a cleaner environment, more equal opportunities, greater individual freedom and richer cultural life amongst citizens of poorer nations. ${ }^{22}$ While Ireogbu notes that development is a systemic realization of the topmost possible and steady improvement of both human and natural resources - the latter in view of the former. ${ }^{23}$ Thus, Onah opines that development is a

\footnotetext{
${ }^{16}$ G. Metzger, Privatization as Delegation, 1367.

${ }^{17}$ N. Murthy, "Entrepreneurship in Small Towns," in J. Samuddin ed. Entrepreneurship Development in India, (New Delhi: Mittal Publication, 1989), 265.

18U.J.F. Ewurum, and G. Ekpunobi, "The Problems and Prospects of SMEs in Nigeria," Journal of Economic Studies, Vol. 7, No. 1, 2008, 163.

${ }^{19}$ A.G. Metu and E.S. Nwokoye, "Entrepreneurship Development in Nigeria: Prospects and Challenges," https:// www.researchgate.net/publication/277021008, Accessed 23/04/2019.

${ }^{20}$ S.B. Oni and I.O. Bello, Community Development: the Backbone for Promoting Socio-Economic Growth, (Zaria: Gask iya Corporation, 1987), 197.

${ }^{21}$ M.P. Todaro, Economics of Developing World, (London: Longman Publishers, 1985), n.p.

${ }^{22}$ L.A. Adamolekun, Framework for Understanding Governance Reforms and Economic Performance: Third Annual F orum on Modernization of Public Services and Governance, (Morocco: CAFRAD, Tangiers, 2007), 236.

${ }^{23}$ P. Iroegbu, The Kpim of Politics, Communalism: Towards Justice in Africa, (Owerri: International University Press, 1996), 236.
} 
continuous, day to day improvement in the capacity of both an individual and society in the control and manipulation of the forces of nature to boost the living standard of the people in a given society. ${ }^{24}$

In a nut shell, development is a combination of the provision of better quality of living based on the availability of and access to the basic necessities of life such as clean water, good food, affordable clothing, shelter, quality education, good health-care services and the opportunity as well as ability to participate in the decision making process and program of government in a society. These indicators of development as pointed out above require funds, focused leadership personnel and policies on the part of the government. Hence all things being equal the more funds available to government, the more likely the provision of these amenities.

\section{Economic Growth}

In the simplest terms, economic growth refers to an increase in aggregate production in an economy. Often, but not necessarily, aggregate gains in production correlate with increased average marginal productivity. ${ }^{25}$ That leads to an increase in incomes, inspiring consumers to open up their wallets and buy more, which means a higher material quality of life or standard of living. In economics, growth is commonly modeled as a function of physical capital, human capital, labour force, and technology. Simply put, increasing the quantity or quality of the working age population, the tools that they have to work with, and the recipes that they have available to combine labour, capital, and raw materials, will lead to increased economic output. 26

According to Uwakaeme, the concept of economic growth has not been quite easy to grasp and measure in real terms. This is so because often on the literature of economics, some authors have variously differentiated economic growth from the term "economic development." 27 Hence he used the term "'economic growth" to describe the positive and sustained increase in aggregate goods and services produced in an economy within a given period of time. He noted that when measured with the population of a given country, then economic growth can be stated in terms of per capita income according to which the aggregate production of goods and services in a given year is divided by the population of the country in the given period.

Uwakaeme further posited that when the increase in the aggregate level of goods and services is deflated by the rate of inflation, real economic growth is realized, otherwise when measured without deflating; it is called nominal economic growth. Hence, economic growth can also be stated in nominal or in real terms. ${ }^{28}$

In his response, Lewis advocated that premature conclusion as a result of mere increase in the aggregate level of production of goods and services in an economy in the prevailing circumstance of threats to global pollution, abysmal lop-sided distribution of aggregate output and income, environmental degradation, prevalence of chronic and deadly disease, abject poverty and the absence of freedom and justice will not give a fare view of the "quality of life"

\footnotetext{
${ }^{24}$ V.C. Onah, "Democratic Governance and Crisis of Development in Nigeria," American Journal of International Polit ics and Development Studies, 1(1), 2005, 129 - 137.

${ }^{25}$ A.W. Lewis, Theory of Economic Growth, (London: George Allen Unwin Press, 1978), 56.

${ }^{26}$ A.W. Lewis, Theory of Economic Growth, 56.

27 O.S. Uwakaeme, "Economic Growth in Nigeria: An Empirical Investigation of Determinants and Causal Relationship (1980 - 2012)," American Journal of Economics, Vol. 5, No. 1, (Michigan: Scientific \& Academic Publishing, 2015), 10.

${ }^{28}$ O.S. Uwakaeme, "Economic Growth in Nigeria: An Empirical Investigation of Determinants and Causal Relationship (1980 - 2012)," American Journal of Economics, Vol. 5, No. 1, 10.
} 
of a citizenry. ${ }^{29} \mathrm{He}$ holds the view that holistic attention should be focused on the total quality of standard of living and not merely on the increase in aggregate output and income because, the application of quantitative measure of aggregate output and income to "quality of life" which would be acceptable to all and sundry that will stand the test of the time is yet to be attained. ${ }^{30}$

Woodford et al perceived the concept as a process by which an economy experiences three main phenomena namely - sustained growth in output, structural changes and institutional changes. ${ }^{31}$ Yesufu saw this as the reason why growth could be enjoyed by many countries but not all experience development, because what leads to a rise in standard of living of the populace is consequentially the combined function of the above three phenomena under the instrumentality of other factors such as physical capital, human capital, labour force as well as technology. ${ }^{32}$

\section{Nigerian Economic Growth}

Uwakaeme describes the Nigerian economy basically in five different ways. ${ }^{33}$ Firstly, he sees the economy as an open economy with international transactions constituting an important proportion of her aggregate economic activity. Hence, the prospects and development of the country's economy is consequently the control of international bodies just like all other developing countries. He agreed with Odedekun who states that over the years, despite the considerable degree of her trade openness, her performance in terms of her economic growth has remained sluggish and discouraging. ${ }^{34}$

Secondly, he sees the Nigeria's trade policy since her independence in 1960 as been characterized by policy swings, from high protectionism to liberalism with the aim of influencing trade process that can promote sustainable economic growth as the object of her trade policy. Unfortunately, it has become very difficult to achieve this objective at present as a result of the political and insecurity state of the nation. ${ }^{35}$

Thirdly, in light of the unstable operating environment, which is characterized by inefficient capital markets, high rate of inflation, unstable polity, stringent policies and fragile financial system, among others, Uwakaeme states that there is also an implicit belief that the Nigerian economic environment has been unable to attract foreign direct investment to its fullest potentials. He saw this as a major setback to the nation's economic growth.

Another major problem as posited by Uwakaeme is the element of fiscal dominance. He stated that a size of fiscal deficit has an implication for domestic savings and investment and ultimately economic growth. ${ }^{36} \mathrm{He}$ explained further that in Nigeria, the main factor underlying

\footnotetext{
${ }^{29}$ A.W. Lewis, Theory of Economic Growth, 20.

${ }^{30}$ A.W. Lewis, Theory of Economic Growth, 20.

${ }^{31}$ M. Woodford and C. Smith, Economic Development, 10 th ed. (New York: Addison Wesley, 2000), 28.

32T.M. Yesufu, "The Nigerian Economy: Growth without Development," The Journal of Uni. Benin Social Science Series for Africa, 1996, 30.

33 O.S. Uwakaeme, "Economic Growth in Nigeria: An Empirical Investigation of Determinants and Causal Relationship (1980 - 2012)," American Journal of Economics, Vol. 5, No. 1, 11.

${ }^{34}$ M.O. Odedokun, Factors Responsible for Poor Economic Growth Performance in Africa in 1970s and 1980: A Cross Sectional Evidence from 42 Countries, 1997, 22.

35T.M. Yesufu, "The Nigerian Economy: Growth without Development," The Journal of Uni. Benin Social Science Series for Africa, 30.

${ }^{36}$ O.S. Uwakaeme, "Economic Growth in Nigeria: An Empirical Investigation of Determinants and Causal Relationship (1980 - 2012)," American Journal of Economics, Vol. 5, No. 1, 11.
} 
these outcomes is the volatility of government expenditure arising from the boom and burst cycle of government revenue which is derived mainly from single export commodity (oil), whose price is also volatile ${ }^{37}$ which Yesufu lamented that to worsen the problem, these expenditures are not channeled to productive sectors of the economy. ${ }^{38}$

Lastly, Uwakaeme stated that prior to Nigeria political independence in 1960, agriculture was the mainstay of the economy and the present heavy reliance on primary commodity has induced adverse terms of trade shocks leading to huge current account deficits and exchange rate volatility and consequently a weak external sector for Nigeria. ${ }^{39}$ Consequently, the trend in the current account amplifies the degree of import-dependence of the Nigerian economy. He lamented that the deployment of the lean resources to finance huge debt service payments crowds out public investment in the productive sectors of the economy and with these developments, achievement of sustainable economic growth have become a difficult task.

On this note and against this background of slow and unpredictable rate of economic growth; as evident with declining productivity signals, and Nigeria being a developing economy characterized by multiplying debt burden, structural disparity and uncertainties, it becomes pertinent to have an insight into the determinants of Nigeria's economic growth as well as their causal relationship with growth.

\section{PRIVATIZATION AND ENTREPRENEURSHIP DEVELOPMENT IN NIGERIAN ECONOMIC GROWTH}

According to Gberevbie, the Structural Adjustment Programme (SAP) of the Ibrahim Badamusi Babangida administration (1985 - 93) formally introduced privatization in Nigeria through the privatization and commercialization Decree of $1988 .{ }^{40} \mathrm{He}$ agrees with Dawodu who states that the participation of the state in enterprises in Nigeria dates back to the colonial era which the coming into power by the labour party in the United Kingdom paved way for the expansion and consolidation of the involvement of the formulated colonial welfare development plan between (1946 - 56). ${ }^{41} \mathrm{~A}$ trend which continued after independence and by 1999 , the estimated invested by successive Nigeria Governments in public owned enterprises have risen up to 800 billion Naira. ${ }^{42}$ Which according to Dawodu, paved way for the privatization and commercialization Decree of 1988 which was part of the Structural Adjustment Programme (SAP) of the Ibrahim Badamosi Babangida administration (1985 - 1993), a neo-liberal development strategy devised by international financial institutions to incorporate national economies into the global market formally introduced Privatization in Nigeria. ${ }^{43}$ One of its main objectives was the pursuance of deregulation and privatization leading to the removal of

\footnotetext{
${ }^{37}$ O.S. Uwakaeme, "Economic Growth in Nigeria: An Empirical Investigation of Determinants and Causal Relationship (1980 - 2012)," American Journal of Economics, Vol. 5, No. 1, 11.

38T.M. Yesufu, "The Nigerian Economy: Growth without Development," The Journal of Uni. Benin Social Science Series for Africa, 30.

${ }^{39}$ O.S. Uwakaeme, "Economic Growth in Nigeria: An Empirical Investigation of Determinants and Causal Relationship (1980 - 2012)," American Journal of Economics, Vol. 5, No. 1, 13.

${ }^{40}$ D.E.I. Gberevbie, "Privatization and the Future of the Public Sector in Nigeria," Nasarawa State University Journal of Administration, 3(1), 2006, 26 - 27.

${ }^{41}$ S.T. Dawodu, "Privatization in Nigeria," Unpublished Paper Presented at a Power Mapping Roundtable Discussion on the Privatisation Programme in Nigeria, 2003, 9.

${ }^{42}$ O. Obasanjo, An Address delivered during the inauguration of the National Council on Privatisation at Presidential Villa, (Abuja: National Council on Privatization of Nigeria, July 1999), n.p.

${ }^{43}$ A. McGrew, "Sustainable Globalization: The Global Politics of Development and Exclusion in the New World Order," in T. Allen and A. Thomas eds. Poverty and Development into the 21 ${ }^{\text {st }}$ Century, (New York: Oxford University Press Inc. 2000), 269.
} 
subsidies, reduction in wage bills and the retrenchment of the public sector ostensible to trim the state down to size.

Dawodu however, was in agreement with Amadi noted that it has been argued that the Nigerian Privatisation exercise is not accompanied or preceded by an articulated and properly phased public sector reform and it will therefore not result in more efficient production of public goods nor will it make any significant positive impact to fiscal balance. ${ }^{44}$

Due to the current economic downturn in Nigeria, there have been a lot of calls and push for entrepreneurship development. The government, organisations as well as different individuals want people to start their own business. This is as a result of the importance of entrepreneurship in economic development of the nation.

Olawale observed that over the years, a high level of entrepreneurship is what has led to the economic growth of many nations in existence today. He cited China is a good example of a nation with an impressive economic growth that came about as a result of the promotion of entrepreneurship among its citizens. ${ }^{45}$ Well developed countries are more interested in entrepreneurs than people in white collar jobs. In the economy today, education is being redefined to produce entrepreneurs and not just job seekers. So, the role of entrepreneurship development in Nigeria economic growth cannot be underestimated especially in times like this. Entrepreneurship in Nigeria today is not what it used to be. ${ }^{46}$ Hence, history very often has a direct impact on what the nation is facing in the present.

Nnadi averred that before the colonial era, majority of Nigerians were basically engaged in one form of entrepreneurial activities or the other and the wealthiest at that time were the traders. Even before money was generally accepted as legal tender, people exchanged what they had in surplus for what they do not have and entrepreneurship was a way for most people then. ${ }^{47}$ Nigeria always was full of people with business acumen and Nigerians always has high moral standard and value for doing business. But the era of the colonial masters who brought their goods and made Nigerians their middlemen changed the mode of entrepreneurship. This was followed by formal education, establishment of companies as well as the advent of oil exploration and exploitation by the colonial masters. He explained further that a lot of young Nigerians were employed by these companies and as many Nigerians began to accept formal education and have a taste of the oil money, there was a rise in the inclination to join the labour force rather than not to be entrepreneur. ${ }^{48}$ Nowadays, there is a high need for entrepreneurship in Nigeria and many organisations and the government have been working on improving entrepreneurship development in the country. ${ }^{49}$ However, as the need and call for entrepreneurship increases, the development of entrepreneurship has in a way been stalled

\footnotetext{
${ }^{44}$ S.T. Dawodu, "Privatization in Nigeria," Unpublished Paper Presented at a Power Mapping Roundtable Discussion on the Privatisation Programme in Nigeria, 9.

45J. Olawale, "Entrepreneurship Development in Nigeria: Problems and Prospect," https://www.legit.ng/1125968entrepreneurship-development-nigeria-problems-prospects.html, Accessed 13/05/2019.

${ }^{46}$ C. Nnadi, "Entrepreneurship Development and its Impact on Small Scale Business Enterprises in Developing Countries: A Nigerian Experience," Unpublished M.A. Project, (Enugu: Department of Management, Faculty of Business Administration, University of Nigeria, 2014), 43.

${ }^{47}$ C. Nnadi, "Entrepreneurship Development and its Impact on Small Scale Business Enterprises in Developing Countries: A Nigerian Experience," Unpublished M.A. Project, 43.

${ }^{48}$ C. Nnadi, "Entrepreneurship Development and its Impact on Small Scale Business Enterprises in Developing Countries: A Nigerian Experience," Unpublished M.A. Project, 43.

${ }^{49} 0$. Ezekwesili, The Wealth and poverty of a Nation, who shall restore the Dignity of Nigeria? (Nsukka: University of Nigeria Press Ltd, 2013), 56.
} 
in the in the last few years. This is because of the problems affecting and limiting its development which include:

i. Inconsistent Government Policies: The fact that there is no continuity in Nigerian government is an indication that there is no good policies that could create necessary conditions for the development of entrepreneurship in the country. ${ }^{50}$ The policies are geared to some people at a particular time and another at another time

ii. Poor State of Infrastructure: Another major challenge affecting the development entrepreneurship in Nigeria is the absence of good infrastructural facilities and the worst of it all is the power sector. The situation where most entrepreneurs have to spend a lot of money on fuel to run generators to sustain their business is not a favourable ground for economic to thrive. Dilapidated roads and poor transport system are other infrastructural facilities confronting entrepreneurs in the nation. These facilities increase the cost of running a business and company which a new entrepreneur cannot afford.

iii. Element of Fiscal Dominance: Another major problem is the element of fiscal dominance. A size of fiscal deficit has an implication for domestic savings and investment and ultimately entrepreneurship development. In Nigeria, the main factor underlying these outcomes is the volatility of government expenditure arising from the boom and burst cycle of government revenue which is derived mainly from single export commodity (oil), whose price is also volatile. To worsen the problem, these expenditures are not channeled to productive sectors of the economy. ${ }^{51}$

iv. Accessing Loans from Financial Institutions: Accessing loans from financial institutions by an average Nigerian is very difficult if not impossible for those looking for funds to setup a business or who already have a small business. The financial institutions are not sure if the young entrepreneur will be able to pay back the loan, they see it as a huge risk lending money to these people hence, the financial institutions demand huge collateral and high-interest rate which small business owners would not be able to provide. This is a discouragement to most Nigerian entrepreneurs and frustrates a lot of promising ideas.

v. Lack of Capital: The lack of capital is the topmost problem affecting and limiting entrepreneurship development over the years. There are thousands of Nigerians with various ideas that could be turned in to real business. But most of them have little or no capital to finance these ideas into reality.

vi. The State of Nigeria Economy: This is also another major call of concern for entrepreneurs in the nation. The state of a nation and its economy plays a significant impact on the level of performance of entrepreneurs in the nation. The socioeconomic problems and unstable economy of the nation have collapsed a lot of businesses in the time past and coupled with security challenges are not helping business in any way. These and many more are some of the challenges affecting entrepreneurship development in Nigeria. ${ }^{52}$

vii. But all hope cannot be lost as a result of those challenges; there are also great prospects for entrepreneurship development in Nigeria. There is an on-going economic transformation plan by the government; solid foundations for economic growth are being laid. Also, the government is making effort to create an enabling

\footnotetext{
${ }^{50}$ D.E.I. Gberevbie and F.O. Iyoha, "Corruption and Cost of Governance in Nigeria," in A.S. Akpotor, A.O. Afolabi, O.S. Odiagbe, O.M. Aigbokhaevbolo and B.O. Iganiga eds. Cost of Governance in Nigeria: An Evaluative Analysis, (Ekpoma : Ambrose Alli University Press, 2007), 29 - 30.

51A. Yusuf, “Privatization: El Rufai's Testimony Jolts Obasanjo," The Nations Newspaper, 13/08/2011, 4.

${ }^{52}$ J. Olawale, "Entrepreneurship Development in Nigeria: Problems and Prospect," https://www.legit.ng/1125968entrepreneurship-development-nigeria-problems-prospects.html, Accessed 13/05/2019.
} 
environment that will allow businesses grow profitably. This is because entrepreneurship development can affect the future of Nigeria in the following ways.

viii. Promotion of Nigeria's Economic Development: The role entrepreneurship development has to play in the economic growth of Nigeria cannot be overemphasized. Evidences abound that there are barriers limiting entrepreneurship development, it is still needed for the country to develop. In 2009, reports showed that small and medium-sized enterprises (SME) in the industrial sector contributed about thirty-seven percent (37\%) of the Gross Domestic Product (GDP) for that year. ${ }^{33}$ It was the second largest contributor after oil sector. So, entrepreneurship development has got to offer and improve the economy of Nigeria. ${ }^{54}$

ix. Creation of Employment Opportunities: The development of entrepreneurship will lead to the creation of employment opportunities, improved technological knowhow and help to reduce the level of unemployment in the country. Entrepreneurship creates new frontiers of employment for many Nigerians. More programmes are being rolled out to encourage and facilitate Small and Mediumsized enterprises (SME's) in Nigeria. In most developed countries, the existence of SME's has provided more jobs for their citizens than the government does. It shows that if entrepreneurship continues to develop in Nigeria, more SME's will arise and in turn reduce unemployment in Nigeria.

x. Improved Standard of Living: Again, the development of entrepreneurship will also improve the standard of living of Nigerians. As more SME's grow, more doors of employment opportunities will be opened, leading an increase in aggregate production in an economy. Often, but not necessarily, aggregate gains in production correlate with increased average marginal productivity. That leads to an increase in incomes, inspiring consumers to open up their wallets and buy more, which means a higher material quality of life or standard of living. This will also reduce crime rate, insecurity and bring about relative peace in the country.

\section{CONCLUSION}

This paper examined privatisation and entrepreneurship development in Nigerian economic growth. Over the years, despite the considerable amount of human capital and natural resources, her performance in terms of her economic growth has remained an enigma and issue of concern to the citizens. Hence, the need for the participation of both government and private sector in the development of entrepreneurship which is a key factor to the growth of the nation's economy cannot be overemphasized. The failure of the government in its privatization policies and serious support for small scale industries has contributed to the underdevelopment of the economy, unemployment, poor standard of living and social vices. It must however be noted that for any country to adequately develop and grow either politically or economically, entrepreneurial development must be first of all put into consideration through investment in education of men and women and in physical capital as well as the quality of the government and its economic policies. After these other things can follow.

\footnotetext{
53F.E. Onah, "The Impact of Economic Globalization on Nigeria's Industrial Sector," Nigerian Journal of Social Sciences, 4(1), 254.

54J. Olawale, "Entrepreneurship Development in Nigeria: Problems and Prospect," https://www.legit.ng/1125968entrepreneurship-development-nigeria-problems-prospects.html, Accessed 13/05/2019.
} 


\section{RECOMMENDATIONS}

Based on the discussions and findings, the study recommends that:

1. The policy making institutions are to take cognizance of the policy implementation effect and design policies in line with the expected magnitude of expected changes.

2. The government needs to work with other organizations and agencies to foster the creation of a better environment for entrepreneurship and private sector of the economy through improvement of the level of infrastructure in the country.

3. The agricultural sector needs to be objectively revitalized. There is a lot of potentials to be tapped there being that agriculture is rooted in the culture of Nigerians.

\section{BIBLIOGRAPHY}

Abdullahi, I.B. "Privatization of Nigerian Public Enterprises: Lessons from Developed Countries," Ilorin Journal of Business and Social Sciences, 9, No. 1 \& 2, 2004.

Abiodun, A.I. "Privatization of Public Corporations in Nigeria: The Fate of the Masses," International Journal of Economic and Development Issues, 5(1 \& 2), 2005.

Adamolekun, L.A. Framework for Understanding Governance Reforms and Economic Performance: Third Annual Forum on Modernization of Public Services and Governance. Morocco: CAFRAD, Tangiers, 2007.

Beeman, J. "Privatization and Political Accountability," Fordham Urban Law Journal, 28(5), 2001.

Dawodu, S.T. "Privatization in Nigeria," Unpublished Paper Presented at a Power Mapping Roundtable Discussion on the Privatisation Programme in Nigeria, 2003.

Devroye, D. "Who wants to Privatize Social Security? Understanding why the Poor are wary of Private Accounts," Public Administration Review, 63(3), 2003.

Dudley, E.R. The Pursuit of Reason: The Economist, 1843 - 1993. Harvard: Harvard Business School Press, 1995.

Ewurum, U.J.F. and Ekpunobi, G. "The Problems and Prospects of SMEs in Nigeria," Journal of Economic Studies, Vol. 7, No. 1, 2008.

Ezekwesili, 0 . The Wealth and poverty of a Nation, who shall restore the Dignity of Nigeria? Nsukka: University of Nigeria Press Ltd, 2013.

Gberevbie, D.E. et al. "Deregulation Policy and Development in Nigeria: The Petroleum Sector Experience, 1999 2014," in Journal of Social Development in Africa, Vol. 30, No. 2, 2015.

Gberevbie, D.E.I. "Privatization and the Future of the Public Sector in Nigeria," Nasarawa State University Journal of Administration, 3(1), 2006.

Gberevbie, D.E.I. and Iyoha, F.O. “Corruption and Cost of Governance in Nigeria," in Akpotor, A.S; Afolabi, A.O; Odiagbe, O.S; Aigbokhaevbolo, O.M. and Iganiga, B.O. eds. Cost of Governance in Nigeria: An Evaluative Analysis. Ekpoma: Ambrose Alli University Press, 2007.

Iroegbu, P. The Kpim of Politics, Communalism: Towards Justice in Africa. Owerri: International University Press, 1996.

Kammerer, J.A. Privatisierung: Typologie - Determinanten - Rechtspraxis - Folgen. Germany: Mohr Siebeck Verlag, 2001.

Lewis, A.W. Theory of Economic Growth. London: George Allen Unwin Press, 1978.

McGrew, A. "Sustainable Globalization: The Global Politics of Development and Exclusion in the New World Order," in Allen, T. and Thomas, A. eds. Poverty and Development into the 21 ${ }^{\text {st }}$ Century. New York: Oxford University Press Inc. 2000.

Metu, A.G. and Nwokoye, E.S. "Entrepreneurship Development in Nigeria: Prospects and Challenges," https://www.researchgate.net/publication/277021008,Accessed 23/04/2019.

Metzger, G. Privatization as Delegation. London: Colum L. Rev, 2003.

Murthy, N. "Entrepreneurship in Small Towns," in Samuddin, J. ed. Entrepreneurship Development in India. New Delhi: Mittal Publication, 1989.

Nnadi, C. "Entrepreneurship Development and its Impact on Small Scale Business Enterprises in Developing Countries: A Nigerian Experience," Unpublished M.A. Project. Enugu: Department of Management, Faculty of Business Administration, University of Nigeria, 2014. 
Obasanjo, O. An Address delivered during the inauguration of the National Council on Privatisation at Presidential Villa. Abuja: National Council on Privatization of Nigeria, July 1999.

Odedokun, M.O. Factors Responsible for Poor Economic Growth Performance in Africa in 1970s and 1980: A Cross Sectional Evidence from 42 Countries, 1997.

Olawale, J. “Entrepreneurship Development in Nigeria: Problems and Prospect," http://www.legit.ng/1125968entreprenuership-development-nigeria-problems-prospects.html, Accessed 13/05/2019.

Onah, F.E. “The Impact of Economic Globalization on Nigeria's Industrial Sector," Nigerian Journal of Social Sciences, 4(1), 2004.

Onah, V.C. "Democratic Governance and Crisis of Development in Nigeria," American Journal of International Politics and Development Studies, 1(1), 2005.

Oni, S.B. and Bello, I.O. Community Development: the Backbone for Promoting Socio-Economic Growth. Zaria: Gaskiya Corporation, 1987.

Savas, E.S. Privatization and Public-Private Partnerships. Chatham, NJ: Chatham House, 2000.

Shirley, M.M. The What, Why, and How of Privatization: A World Bank Perspective, 60. Fordham: Pritchard Press 1992.

Todaro, M.P. Economics of Developing World. London: Longman Publishers, 1985.

Uwakaeme, O.S. "Economic Growth in Nigeria: An Empirical Investigation of Determinants and Causal Relationship (1980 - 2012)," American Journal of Economics, Vol. 5, No. 1. Michigan: Scientific \& Academic Publishing, 2015.

Woodford, M. and Smith, C. Economic Development, 10 ${ }^{\text {th }}$ ed. New York: Addison Wesley, 2000.

Yesufu, T.M. "The Nigerian Economy: Growth without Development," The Journal of Uni. Benin Social Science Series for Africa, 1996.

Yusuf, A. “Privatization: El Rufai’s Testimony Jolts Obasanjo,” The Nations Newspaper, 13/08/2011. 